\title{
MENTAL ILLNESS, HARASSMENT AND LABOUR LAWS: SOME THOUGHTS ON HARASSMENT BY EMPLOYEES SUFFERING FROM MENTAL ILLNESS*
}

\author{
Moffat Maitele Ndou \\ LLB LLM \\ Lecturer, Faculty of Law \\ North-West University
}

SUMMARY

Section 23 of the Constitution of the Republic of South Africa, 1996 provides that everyone has the right to fair labour practices. Section 9 of the Constitution prohibits unfair discrimination directly or indirectly against anyone on one or more grounds, including among others disability. In terms of section 6(1) of the Employment Equity Act (EEA), no person may unfairly discriminate, directly or indirectly, against an employee, in any employment policy or practice, on one or more grounds, including among others disability or on any other arbitrary ground. Section 6(1) applies to employees, which includes applicants; but it is only limited to conduct occurring within the scope of an "employment policy or practice". In Marsland v New Way Motor \& Diesel Engineering (2009) 30 ILJ 169 (LC), the court concluded that discrimination based on the fact that a person suffers from a mental health problem, has the potential to impair the fundamental dignity of that person as a human being, or to affect them in a comparably serious manner. Consequently, discrimination based on mental illness must be treated as a prohibited ground of discrimination. However, as it was pointed out in Hoffmann $v$ South African Airways 2001 (1) SA 1 (CC), it may in some instances be justified to discriminate on the ground of mental illness, if it is proved that the discrimination is based on an inherent requirement of a job. Section 15 of the EEA requires that, when the employer implements affirmative action measures, he/she must make reasonable accommodation for people from designated groups, in order to ensure that they enjoy equal opportunities and are equitably represented in the workforce of a designated employer. Section 1 defines "reasonable accommodation" as "any modification or adjustment to a job or to the working environment that will enable a person from a designated group to have access to or participate or advance in employment". Section 6(3) of the EEA provides that harassment is a form of discrimination and is prohibited among others on the ground of disability or any other arbitrary ground. Harassment is also a form of misconduct. The employer is required to take reasonable steps to prevent harassment and failure to do so, the employer is liable for such harassment. Where an employee who has a mental illness, commits an act of harassment against another employee, the employer should take into account its duty to reasonably accommodate the offending employee, the duty to take steps to prevent harassment

Based on a paper presented at the Nelson Mandela University Labour Law Conference on "Labour Dispute Resolution, Substantive Labour Law and Social Justice Developments in South Africa, Mauritius and Beyond" from 19-21 July 2019 in Mauritius. 
and the fact that it may be automatically unfair to dismiss an employee for misconduct which was committed because of mental illness.

\section{$1 \quad$ INTRODUCTION}

Dismissal of an employee on the grounds of mental illness is automatically unfair in terms of the Labour Relations Act (LRA). ${ }^{1}$ In Jansen $v$ Legal Aid $S A,{ }^{2}$ the Labour Court found that where an employer dismisses an employee, suffering from a mental illness, the dismissal would be automatically unfair; if such misconduct was inextricably linked to the mental illness. The court found that the employer has a duty to accommodate the offending employee.

Harassment is a form of misconduct. Where an employee, who has a mental illness commits acts of harassment, how should the employer handle such misconduct, taking into account that it has a duty to provide a safe working environment and a duty to accommodate employees who have a mental illness? This submission will explore the legal implications in this regard.

In order to comprehensively explore the problem, it will be necessary first to define mental illness. The prohibition on unfair discrimination on the ground of disability and the employer's duty to reasonably accommodate an employee suffering from mental illness will be discussed. The implications of Jansen v Legal Aid $S A^{3}$ on harassment cases will then be explored. This will be done, taking into account the liability of the employer for harassment in the workplace.

\section{DEFINING MENTAL ILLNESS}

Swanepoel ${ }^{4}$ points out that it is very difficult to define the concept of mental illness. She makes the following observation in making that point:

"This concept, like many other concepts in medicine and science, lacks a consistent operational definition that covers all situations. Mental illnesses have been defined by a variety of terms, such as distress, disadvantage, disability, inflexibility, irrationality, and statistical deviation. Each is a useful indicator for a mental illness, but none is equivalent to the concept, and different situations call for different definitions."

The Mental Health Care Act ${ }^{6}$ (MHCA) defines mental illness as a positive diagnosis of a mental health-related illness in terms of accepted diagnostic criteria made by an authorised mental health care practitioner. ${ }^{7}$ The MHCA requires that there must be a positive diagnosis, made by a mental health care practitioner, in terms of accepted diagnostic criteria. The Employment

55 of 1996.

(2018) 39 ILJ 2024 (LC).

Supra.

Swanepoel "Legal Aspects With Regard to Mentally III Offenders in South Africa" 2015 18(1) PER 3238.

Ibid.

17 of 2002.

See $\mathrm{s} 1$ of the Mental Health Care Act 17 of 2002. 
Equity $\mathrm{Act}^{8}$ defines mental illness as a form of disability. ${ }^{9}$ The EEA refers to mental illness as a "mental impairment". ${ }^{10}$ Mental impairment is defined as "a clinically recognised condition or illness that affects a person's thought processes, judgment or emotions". ${ }^{11}$

It is submitted that the MHCA and the EEA do not provide a definitive answer as to what constitutes mental illness. Further, they do not prescribe which diagnostic criteria are accepted to determine what mental illness is. ${ }^{12}$ However, in practice, the World Health Organisation's (WHO) ICD-10 Classification of Mental and Behavioral Disorders - Clinical Descriptions and Diagnostic Guidelines and the DSM-5 are routinely relied upon as diagnostic tools. ${ }^{13}$ The DSM-5 defines mental disorder as "a clinically significant behavioural or psychological syndrome or pattern that occurs in an individual and that is associated with present distress or disability or with a significantly increased risk of suffering death, pain, disability, or an important loss of freedom".

The phrase "mental defect" is also used instead of mental disorder or mental illness and it refers to a condition where the person has significantly below average intellectual functioning, which is accompanied by significant limitations in several areas of adaptive functioning such as communication, social/interpersonal skills and self-direction. ${ }^{14}$ In $S$ v Stellmacher,${ }^{15}$ the court defined "mental illness" or "mental defect" as a pathological disturbance of a person's mental capacity. Swanepoe ${ }^{16}$ defines mental illness as a disorder (or disease) of the mind that is judged by experts to interfere substantially with a person's ability to cope with the demands of life on a daily basis. Generally, mental illness will include but is not limited to, anxiety and depression, agoraphobia and panic disorder, mood affective disorders, and schizophrenia.

The diagnosis of mental illness must be made by a mental health care practitioner. ${ }^{18}$ The MHCA defines a mental health care practitioner as a psychiatrist, medical practitioner or nurse, occupational therapist, psychologist or social worker trained to provide mental health care services.

\footnotetext{
55 of 1998.

See $\mathrm{s} 1$ of the Employment Equity Act 28 of 1998. See also Code of Good Practice on Employment of Persons with Disabilities.

Ibid.

Clause 5 of the Code of Good Practice on Employment of Persons with Disabilities.

Landman and Landman A Practitioner's Guide to the Mental Health Care Act (2014) 12.

Ibid.

See Tredoux, Foster, Allan, Cohen and Wassenaar Psychology and Law ( 2005).

1983 (2) SA 181 (SWA) 187.

Swanepoel 2015 PER 3239.

WHO's ICD-10 Classification of Mental and Behavioral Disorders - Clinical Descriptions and Diagnostic Guidelines.

$18 \mathrm{~S} 1$ of the MHCA.
}

19 Ibid. 


\section{EMPLOYMENT OF A MENTALLY ILL EMPLOYEE}

\section{Prohibition of discrimination}

Section 23 of the Constitution of the Republic of South Africa, 1996 (the Constitution) provides that everyone has the right to fair labour practices. Section 9 of the Constitution prohibits unfair discrimination directly or indirectly against anyone on one or more grounds, including race, gender, sex, pregnancy, marital status, ethnic or social origin, colour, sexual orientation, age, disability, religion, conscience, belief, culture, language and birth.

In terms of section $6(1)$ of the EEA, no person may unfairly discriminate, directly or indirectly, against an employee, in any employment policy or practice, on one or more grounds, including, inter alia, disability, ${ }^{20}$ or on any other arbitrary ground. Section 6(1) applies to employees, which includes applicants; but it is limited to conduct occurring within the scope of an "employment policy or practice". ${ }^{21}$ In Hoffmann v South African Airways, ${ }^{22}$ the court found that the prohibition of unfair discrimination is necessitated by the recognition that under the Constitution, all human beings must be accorded equal dignity. Human dignity is impaired when a person is unfairly discriminated against. ${ }^{23}$ When determining the unfairness of the discrimination, it is important to look at various factors including the position of the victim of discrimination in society, the purpose sought to be achieved by the discrimination, the extent to which the rights or interests of the victim of discrimination have been affected, and whether the discrimination has impaired the human dignity of the victim. ${ }^{24}$ The determining factor regarding unfair discrimination is its impact on the person discriminated against.

In Marsland $v$ New Way Motor \& Diesel Engineering, ${ }^{26}$ the court considering whether discrimination on the basis of mental illness was fair, found that discrimination based on the fact that a person suffers from a mental health problem, has the potential to impair the fundamental dignity of that person as a human being, or to affect them in a comparably serious manner. ${ }^{27}$ Therefore, discrimination based on mental illness must be treated

20 This includes persons suffering from a mental illness. See Ngwena "Deconstructing the Definition of 'Disability' Under the Employment Equity Act: Social Deconstruction” 2006 SAJHR 613 on a comprehensive discussion of the definition of disability in terms of the EEA.

21 Du Toit, Bosch, Woolfrey, Godfrey, Cooper, Giles, Bosch and Rossouw Labour Relations Law: A Comprehensive Guide (2011) 575. The EEA defines "employment policy or practice" to include, advertising and selection criteria; appointment and the appointment process; job classification and grading; remuneration, employment benefits and terms and conditions of employment; job assignments; the working environment and facilities; training and development; performance evaluation systems; promotion; transfer; demotion; disciplinary measures other than dismissal; and dismissal.

22 Supra par 27

23 Hoffmann $v$ South African Airways supra par 27.

24 Ibid.

25 Ibid.

26 Supra. See also Harksen v Lane NO 1997 (11) BCLR 1489 (CC); 1998 (1) SA 300 (CC) on the test for discrimination.

27 Marsland v New Way Motor \& Diesel Engineering supra 193D-F. 
as a prohibited ground. ${ }^{28}$ In EWN v Pharmaco Distribution (Pty) $L t d{ }^{29}$ the court frowned upon the dismissal of an employee who has a mental illness, for refusing to submit to medical testing. The court found that the dismissal based on refusal of an employee, as a person with a bipolar condition, to undergo a medical examination, which she would not have been required to undergo, but for her condition was an act of unfair discrimination in terms of section 6 of the EEA. ${ }^{30}$

However, as it was pointed out in Hoffmann $v$ South African Airways, ${ }^{31}$ it may, in some instances be justified to discriminate on the grounds of disability (including mental illness), if it is proved that the discrimination is based on an inherent requirement of the job. ${ }^{32}$ Grogan ${ }^{33}$ points out that the purpose of section $6(2)(b)$ of the EEA is to recognise that, notwithstanding the need to eradicate discrimination from the workplace, there may be situations in which possession or lack thereof of one or more of the listed grounds may be relevant to certain work. He goes further to state that the ground must be linked to the inherent requirement of the job. ${ }^{34}$

Du toit et $a l^{35}$ point out that the EEA does not indicate what test should be used to determine whether an inherent requirement exists. The authors suggest that the notion of the inherent requirement of a job should be tested against the following criteria: ${ }^{36}$

(a) It must be a permanent feature of the job;

(b) It must be integral to the job; that it cannot be changed without materially altering the job itself; and

(c) It must be essential to the performance of the work in question.

In Whitehead $v$ Woolworths (Pty) $L t d^{37}$ the court found that the concept of inherent requirement of a job implies that the indispensable attribute must be job-related. The court rejected the suggestion that the requirement of uninterrupted job continuity was an inherent job requirement. ${ }^{38}$ The court observed that this was a distortion of the concept of inherent requirement of

29 (2016) 37 ILJ 449 (LC) par 49.

30 EWN v Pharmaco Distribution (Pty) Ltd supra par 49. The court also observed that "The stigmatising effect of being singled out on the basis of an illness that she was manaing, notwithstanding the absence of any objective basis for doubting her ability to perform, is obvious. The act of requiring her to submit to the examination in the circumstances was also an act of unfair discrimination in terms of s 6 of the Employment Equity Act."

31 Supra.

32 See $s 6(2)(b)$ of the EEA, which provides that "it is not unfair discrimination to- distinguish, exclude or prefer any person on the basis of an inherent requirement of a job". See Also ILO Convention 111, which provides that "[a]ny distinction, exclusion or preference in respect of a particular job based on the inherent requirements thereof shall not be deemed to be discrimination". Grogan Dismissal, Discrimination \& Unfair Labour Practices (2007) 107.

34 See article 1 of the ILO Convention 111

5 Du Toit et al Labour Relations Law 604.

36 Du Toit et al Labour Relations Law 608.

37 (1999) 20 ILJ 2133 (LC) par 37 . The Woolworths judgment was reversed on appeal, but the majority held for the company for different reasons.

$38 \quad$ Whitehead $v$ Woolworths (Pty) Ltd supra par 37. 
a job..$^{39}$ If the job can be performed without the particular requirement, such requirement cannot be regarded as inherent to the job, and therefore it is not protected. ${ }^{40}$

The Labour Court has taken the approach of interpreting the phrase "inherent requirement of the job", in a manner which militates against an expansive reading of the phrase, because "any legislatively formulated justification of discrimination constitutes, in effect, a limitation on the constitutionally entrenched right to equality".

It is accepted that the following would not amount to an inherent requirement of the job: ${ }^{42}$

(a) Evaluation of the person's competency based on the stereotypes of the group that the person belongs to.

(b) Requirements based on preferences of the employer and clients.

(c) The requirement that the job be performed in a particular way, when it may be performed in different ways.

(d) Requirements based on the ability to perform light or heavy work.

In the context of dismissal for misconduct, section 187(1)(f) of the LRA, ${ }^{43}$ provides that dismissal is automatically unfair if the reason for the dismissal is that the employer directly or indirectly, unfairly discriminated against the employee on the ground of disability. The court in Jansen $v$ Legal Aid SA, ${ }^{44}$ deciding whether the dismissal of an employee who has a mental illness (depression), for misconduct, amounted to an automatically unfair dismissal in terms of section 187(1)(f), found that where the dismissal is based on conduct which is inextricably linked to mental illness, the dismissal will be automatically unfair. ${ }^{45}$

\section{Reasonable accommodation}

Section 15 of the EEA requires that, when the employer implements affirmative action measures, he/she must make reasonable accommodation for people from designated groups ${ }^{46}$ in order to ensure that they enjoy equal opportunities and are equitably represented in the workforce of a designated employer. Section 1 of the EEA defines "reasonable accommodation" as "any modification or adjustment to a job or to the working environment that will enable a person from a designated group to have access to or participate or advance in employment". Section 15 of the EEA recognises

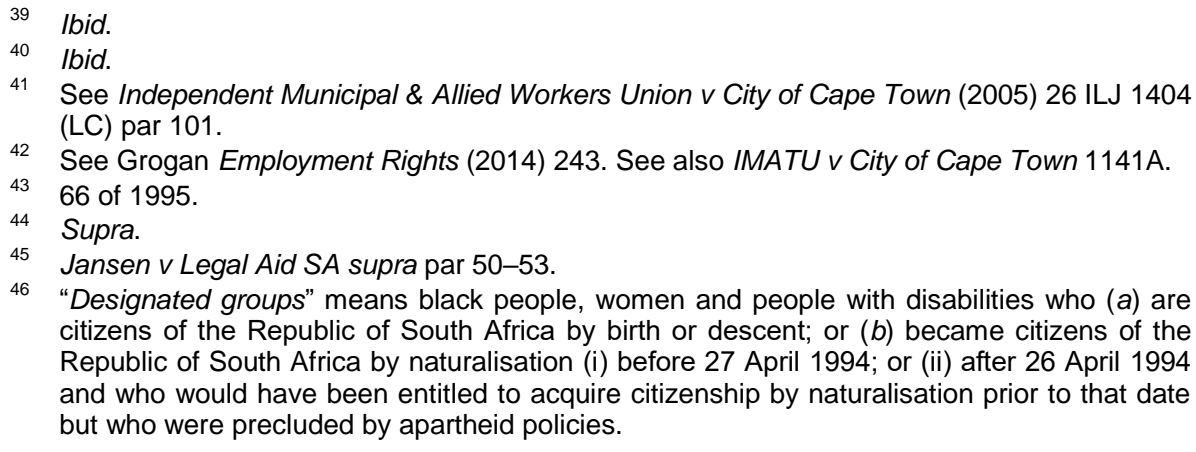

46 "Designated groups" means black people, women and people with disabilities who (a) are citizens of the Republic of South Africa by birth or descent; or $(b)$ became citizens of the Republic of South Africa by naturalisation (i) before 27 April 1994; or (ii) after 26 April 1994 and who would have been entitled to acquire citizenship by naturalisation prior to that date but who were precluded by apartheid policies. 
that when law is applied in a neutral manner, it may have discriminatory consequences on persons with disabilities. ${ }^{47}$

The definition of reasonable accommodation above is in line with the International standard. The United Nations Convention on the Rights of Persons with Disabilities, 2007 (UNCRPD) defines reasonable accommodation as a "necessary and appropriate modification and adjustments not imposing a disproportionate or undue burden, where needed in a particular case, to ensure to persons with disabilities the enjoyment or exercise on an equal basis with others of all human rights and fundamental freedoms". ${ }^{48}$ Article 5(3) of the UNCRPD provides that in order to promote equality and eliminate discrimination, states parties must take all appropriate steps to ensure that reasonable accommodation is provided to persons with disability. The UNCRPD further provides that state parties must ensure that reasonable accommodation is provided to persons with disabilities in the workplace. ${ }^{49}$

Further giving effect to the provisions of the UNCRPD above, item 6 of the Code of Good Practice on Employment of Persons with Disabilities (the Disability Code) in terms of the EEA provides that employers must reasonably accommodate the needs of persons with disabilities. ${ }^{50}$ The purpose of reasonable accommodation is to "reduce the impact of the impairment on the person's capacity to fulfil the essential functions of a job".

The Disability Code makes it clear that the requirement of reasonable accommodation applies to applicants and employees with disabilities who are suitably qualified for the job. ${ }^{52}$ The obligation to make reasonable accommodation may arise when an applicant or employee voluntarily discloses a disability or when it is reasonably self-evident to the employer. ${ }^{53}$ The nature of the accommodation will depend on the individual, the degree and nature of impairment and its effect on the person, as well as on the job and the working environment and includes: ${ }^{54}$

(a) Adapting existing facilities to make them accessible to persons with disabilities;

(b) Adapting existing equipment or acquiring new equipment including computer hardware and software to make it accessible to persons with disabilities;

(c) Reorganising workstations;

$47 \quad H M v$ Sweden Communication 3/2011 (committee on the rights of persons with disabilities). See also Grobbelaar-du Plessis and Nienaber "Disability and Reasonable Accommodation: HM v Sweden Communication 3/2011 (committee on the rights of persons with disabilities)" 201430 SAJHR 366 and MEC for Education Kwazulu-Natal v Pillay 2008 (1) SA 474 (CC).

48 Art 2 of the UNCRPD.

49 Art $27(1)(i)$ of the UNCRPD.

50 Item 6.1 of the Code of Good Practice on Employment of Persons with Disabilities 2015. In terms of Item 6.2 the aim of the accommodation is to reduce the impact of the impairment of the person's capacity to fulfil the essential functions of a job.

51 Item 6.1 of the Code of Good Practice on Employment of Persons with Disabilities 2015.

52 Item 6.3 of the Code of Good Practice on Employment of Persons with Disabilities 2015.

53 Item 6.4 of the Code of Good Practice on Employment of Persons with Disabilities 2015.

54 Item 6.9 of the Code of Good Practice on Employment of Persons with Disabilities 2015. 
(d) Changing training and assessment materials and systems;

(e) Restructuring jobs so that non-essential functions are reassigned;

(f) Adjusting working conditions, including working time and leave; and

(g) Providing specialised supervision, training and support for persons with disabilities in the workplace.

Where the employee's action amounts to a misconduct and such misconduct is linked to the mental illness, which the employer is aware of, the employer has a duty to reasonably accommodate the employee and failure to do so will amount to unfair discrimination and/or unfair dismissal. ${ }^{55}$

The employer is not obliged to accommodate a qualified applicant or an employee with a disability if this would impose an unjustifiable hardship on the business of the employer. ${ }^{56}$ There is no hard and fast rule as to what constitutes undue hardship, and each case has to be determined on its own facts. ${ }^{57}$ If the employer cannot reasonably accommodate the disabled employee without unjustifiable hardship, the employer may dismiss the employee. ${ }^{58}$ The Disability Code defines "unjustifiable hardship" as an action that requires significant or considerable difficulty or expense from the employer. ${ }^{59}$ The factors that may be considered in deciding whether the reasonable accommodation would cause unjustifiable hardship include, amongst other things, the effectiveness of the accommodation and the extent to which it would seriously disrupt the operation of the business. ${ }^{60}$

The Labour Court in Standard Bank of SA v Commission for Conciliation, Mediation \& Arbitration $^{61}$ recognised that unjustifiable hardship means "[m]ore than mere negligible effort" ${ }^{62}$ Similar to the notion of reasonable accommodation, the concept of unjustified hardship also imports a proportionality test. ${ }^{63}$ Some hardship is envisaged, and a minor interference or inconvenience does not come close to meeting the threshold, but a substantial interference with the rights of others does. ${ }^{64}$ To succeed with the claim for unjustified hardship, the employee has to prove special circumstances. ${ }^{65}$ Considering the limits of reasonable accommodation, the arbitrator, in National Education Health \& Allied Workers Union on behalf of Lucas and Department of Health (Western Cape), ${ }^{66}$ made the following observation:

Jansen $v$ Legal Aid SA supra.

Item 6.11 of the Code of Good Practice on Employment of Persons with Disabilities 2015. Item 6 (12) defines unjustified hardship as "action that requires significant or considerable difficulty or expense. This involves considering, amongst other things, the effectiveness of the accommodation and the extent to which it would seriously disrupt the operation of the business."

57 Standard Bank of SA v Commission for Conciliation, Mediation \& Arbitration (2008) 29 ILJ 1239 (LC).

58 Ibid.

59 Item 6 of the Code of Good Practice on Employment of Persons with Disabilities 2015.

60 Ibid.

Supra.

Standard Bank of SA v Commission for Conciliation, Mediation \& Arbitration supra par 98.

Ibid.

Ibid.

Ibid.

(2004) 25 ILJ 2091 (BCA) par 33. 
"It would seem that in deciding what is reasonable depends on the circumstances of the workplace and the employee. The employer and the employee should adopt a collaborative problem-solving approach to modify employment practices to give the employee with the disability opportunities for job performance that would be similar, if not equal to a similarly situated employee who does not have any disabilities. How much and what kind of adjustments are 'reasonable' is difficult to determine and I do not consider I need to determine that now. The goal is ultimately to facilitate greater retention and employment for people with disabilities. Of course one would have to consider the extent, the purpose, arrangements of the accommodation and the employer's resources."

The employer is only obliged to accommodate an employee with a disability if the employee is a "suitably qualified person". ${ }^{67}$ Section 20(3) of the EEA provides that a person may be suitably qualified for a job as a result of any one of, or any combination of that person's formal qualifications, prior learning, relevant experience, or capacity to acquire, within a reasonable time, the ability to do the job. The employer is obliged when determining whether the person is suitably qualified, to consider the factors listed in section 20(3) and make a determination based on one or a combination of those factors.

\section{HARASSMENT IN THE WORKPLACE}

Section 6(3) of the EEA provides that harassment is a form of discrimination and is prohibited on the listed grounds or any other arbitrary ground. Pretorius et $a^{{ }^{99}}$ argue that this requires implementing harassment policies with sufficient preventative measures and instituting effective procedures and mechanisms for dealing with harassment in the workplace.

The EEA ${ }^{70}$ and the $\mathrm{LRA}^{71}$ do not provide a definition of harassment. However, the direction as to what harassment is may be found in the definitions provided in The Protection from Harassment Act (the Harassment Act $)^{72}$ and the Promotion of Equality and Prevention of Unfair Discrimination Act (PEPUDA) ${ }^{73}$ PEPUDA defines harassment as: ${ }^{.4}$

67 Pretorius, Klinck and Ngwena Employment Equity Law (2018) 6-4. See also Item 7.2.1 of the Code of Good Practice on Employment of Persons with Disabilities 2015.

68 S 20(4) of the EEA.

69 Pretorius et al Employment Equity Law 6-4.

70 In the context of sexual harassment, item 4 of the Amended Code of Good Practice on the Handling of Sexual Harassment Cases in the Workplace (Sexual Harassment Code) defines sexual harassment as an unwelcome conduct of a sexual nature that violates the rights of an employee and constitutes a barrier to equity in the workplace. Item 4 further requires that such unwelcome conduct of a sexual nature, must be viewed in light ofwhether the harassment is on the prohibited grounds of sex and/or gender and/or sexual orientation; whether the sexual conduct was unwelcome; the nature and extent of the sexual conduct; and the impact of the sexual conduct on the employee. Where an employee has an affair or sexual relationship with a manager or a co-worker it will not amount to sexual harassment because it embarrasses the employer. See $G \vee K$ 1988) 9 ILJ 314 (IC) and Steynberg v Coin Security Group (Pty) Ltd (1998) 19 ILJ 304 (LC).

7166 of 1995.

7217 of 2011.

734 of 2000.

74 See $s 11$ of PEPUDA. 
"unwanted conduct which is persistent or serious and demeans, humiliates or creates a hostile or intimidating environment or is calculated to induce submission by actual or threatened adverse consequences and which is related to

(a) sex, gender or sexual orientation; or

(b) a person's membership or presumed membership of a group identified by one or more of the prohibited grounds or a characteristic associated with such group."

This definition does not apply to the workplace. The provisions of PEPUDA do not apply to persons covered by the provisions of the EEA. ${ }^{75}$

The Harassment Act provides a comprehensive definition of harassment. The Harassment Act is not specifically directed towards the workplace, but its ambit is wide enough to include them. Landman and Ndou argue that the Harassment Act adds to the remedies available to an employee for nonsexual and sexual harassment in terms of the EEA and the LRA. ${ }^{76}$ In Mnyandu $v$ Padayachi ${ }^{77}$ the court agreed with Landman and Ndou's observation. The court found that the Harassment Act has application and may prove useful in the workplace environment as it enhances the remedies for harassment in the workplace available under other legislation. ${ }^{78}$

The definition of harassment in terms of the Harassment Act is broad enough to include stalking and bullying; this can be done verbally or through electronic devices. ${ }^{79}$ Landman and Ndou argue that section 9(5) of the Harassment Act provides four defences, namely whether the conduct constituting harassment was engaged $-^{80}$

"(a) for the purpose of detecting or preventing an offence;

(b) to reveal a threat to public safety or the environment;

(c) to reveal that an undue advantage is being or was given to a person in a competitive bidding process; or

(d) to comply with a legal duty."

See s 5(3) of PEPUDA.

76 Landman and Ndou "The Protection from Harassment Act and its Implications for the Workplace" 2013 22(9) CLL 8187.

[2016] 4 All SA 110 (KZP).

Mnyandu v Padayachi supra par 42.

See $\mathbf{s} 1$ of the Harassment Act. Harassment is defined as-

"directly or indirectly engaging in conduct that the respondent knows or ought to know-

(a) causes harm or inspires the reasonable belief that harm may be caused to the complainant or a related person by unreasonably-

(i) following, watching, pursuing or accosting of the complainant or a related person, or loitering outside of or near the building or place where the complainant or a related person resides, works, carries on business, studies or happens to be;

(ii) engaging in verbal, electronic or any other communication aimed at the complainant or a related person, by any means, whether or not conversation ensues; or

(iii) sending, delivering or causing the delivery of letters, telegrams, packages, facsimiles, electronic mail or other objects to the complainant or a related person or leaving them where they will be found by, given to, or brought to the attention of, the complainant or a related person; or

(b) amounts to sexual harassment of the complainant or a related person.' 'harm' means any mental, psychological, physical or economic harm.

80 Landman and Ndou 2013 CLL 85. 
However, the authors acknowledge that these defences are not true defences in the sense that if the party proves them or one of them it will defeat the application. ${ }^{81}$ These defences are factors that must be taken into account in addition to any other factors for the purpose of deciding whether the conduct of a respondent is unreasonable as referred to in paragraph (a) of the definition of harassment. ${ }^{82}$ However, these factors may be weighty factors as compared to the other factors. ${ }^{83}$

The High Court of South Africa has had the opportunity to consider the definition of "harassment" in terms of the Harassment Act. In Mnyandu $v$ Padayachi, ${ }^{84}$ the respondent had been granted a protection order in terms of section 2(1) of the Harassment Act against the appellant. The respondent had alleged that the appellant had harassed and subjected him to slander, false allegations and defamation in an email she had sent to their colleagues, where they were both employed. The respondent sought a protection order because the adverse impact of the false allegations reached beyond the workplace into his personal life and was detrimental to his reputation in the community in which he lived. He persisted that the appellant had unreasonably, and in bad faith, sent the email containing false and malicious allegations against him.

The court had to decide whether the appellant's conduct in sending the email in which the appellant made false allegations against the respondent constituted harassment in terms of the Harassment Act. The court noted that given the comprehensive nature of the Harassment Act, it was necessary for the court to define "harassment". 85 The court warned that if the term "harassment" was given a broad definition, the consequences were a plethora of applications premised on conduct not contemplated by the Harassment Act. ${ }^{86}$ However, a restrictive or narrow interpretation may unduly compromise the purpose of the Harassment Act and the constitutional protection it offers. ${ }^{87}$ After adopting a purposive approach and conducting a comparative analysis, the court concluded that although the definition does not refer to "a course of conduct" the conduct engaged in must necessarily either have a repetitive element which makes it oppressive and unreasonable, thereby tormenting or instilling serious fear or distress in the victim; alternatively the conduct must be of such an overwhelmingly oppressive nature that a single act has the same consequences, as in the case of a single protracted incident when the victim is physically stalked. ${ }^{88}$ It is submitted that the interpretation provided in Mnyandu $v$ Padayachi ${ }^{89}$ is a correct interpretation of the term harassment.

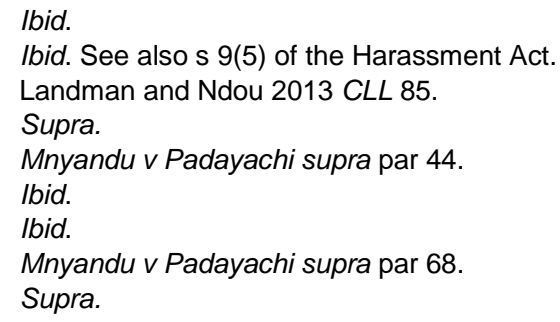




\section{DUTY OF THE EMPLOYER TO PROVIDE A SAFE WORKING ENVIROMENT AND LIABILITY OF THE EMPLOYER FOR HARASSMENT}

The employer owes a common law duty to its employees to take reasonable care for their safety. ${ }^{90}$ The failure to comply with the duty may result in liability in terms of delict or in terms of the Compensation for Occupational Diseases and Injuries Act, 1993 (COIDA). ${ }^{91}$

Section 60 of the EEA provides that after harassment is reported against an employee, the employer must consult all the relevant parties and take steps to eliminate the harassment. If the employer fails to take reasonably practicable steps, and it is proved that an employee has contravened the provisions of the EEA, the employer will also be deemed to have contravened the provisions of the EEA. ${ }^{92}$

Section 60 has created confusion with respect to what needs to be proved in order to place liability on the employer for failure to take reasonable steps to prevent harassment. ${ }^{93}$ Much of the confusion is whether in terms of section 60(4), the phrase "to ensure that the employee would not act in contravention of [the EEA]" means that the employer take steps in advance to eliminate future conduct or refers to steps the employer must take immediately following a report of harassment. ${ }^{94}$ In Mokoena $v$ Garden Art (Pty) $L t d,{ }^{95}$ the Labour Appeal Court took the approach that the employer will only be liable if the employer knew about the harassment and failed to take proper steps to prevent or eliminate or prohibit such harassment. This suggests that the employer would only be liable if it failed to eliminate future conduct of harassment.

90 Van Deventer $v$ Workmen's Compensation Commissioner 1962 (4) All SA 64 (T); 19624 SA 28 (T).

91 See Landman and Ndou "Some Thoughts on Developments Regarding the Recovery of Damages for Pure Psychiatric or Psychological Injury Sustained in the Workplace" 201536 ILJ 2460; Hirsch Appliance Specialists v Shield Security Natal (Pty) Ltd 1992 (1) All SA 84 (D); and Media 24 Ltd v Grobler 2005 (3) All SA 297 (SCA). See also Whitcher "Two Roads to an Employers Vicarious Liability for Sexual Harassment: Grobler $v$ Naspers BPK en ' $n$ Ander and Ntsabo v Real Security CC" 200425 ILJ 1907.

92 S 60(2)-(4) of the EEA. See also Piliso v Old Mutual Life Assurance Co (SA) (2007) 28 ILJ 897 (LC).

93 Liberty Group Ltd v MM [2017] 10 BLLR 991 (LAC) par 35. In this case the employee resigned because she had been sexually harassed by her manager. After incidents of sexual harassment, the employee reported the sexual harassment during a discussion for her salary. The employee was informed to consult the harassment policy and determine whether the conduct amounted to sexual harassment and if so to determine the procedure for lodging a complaint. The employee obtained the forms to lodge the complaint but did not submit such forms after he received a call from her manager informing her that he was aware that she had been in contact with human resources. The employee attempted to resigned, but withdrew the resignation letter after she was convinced by her team leader. After two weeks no steps had been taken to investigate the matter. The employee decided to resign and referred the matter to the CCMA.

94 Liberty Group Ltd v MM supra par 36.

95 [2008] 5 BLLR 428 (LC) par 42-43. 
The Labour Appeal Court, in Liberty Group Ltd $v M M^{96}$ found that the employer will be liable if the employer failed to take reasonable steps to prevent the harassment and have also failed to do everything reasonably practicable to prevent continued harassment. ${ }^{97}$ The court accepted the requirement for liability of the employer, as stated in Potgieter $v$ National Commissioner of the SA Police Service. ${ }^{98}$ The court recognised the following requirements: ${ }^{99}$

a) The harassment complained of must have been committed by another employee.

b) The harassment constitutes unfair discrimination.

c) The harassment took place in the workplace.

d) The harassment was immediately brought to the attention of the employer.

e) The employer was aware of the incident of harassment.

f) The employer failed to consult all relevant parties, or take the necessary steps to eliminate the conduct.

g) The employer failed to take all reasonable and practical measures to ensure that employees did not act in contravention of the EEA.

The court in Liberty Group $L t d v M M,{ }^{100}$ concluded that the fact that the court in Potgieter $v$ National Commissioner of the SA Police Service ${ }^{101}$ used the phrase "did not act in contravention of the EEA", instead of "would not act in contravention of the EEA" as provided in section 60(4) of the EEA indicates that the employer would be liable if it failed to take reasonable steps to prevent harassment, after the harassment was brought to its attention, even if no further act of harassment occurs. This is a different approach to that taken in Mokoena $v$ Garden Art (Pty) Ltd. ${ }^{102}$ The Labour Appeal Court found that this is the interpretation which is in harmony with the purpose of the EEA.

\section{MENTALLY ILL EMPLOYEE AS A PERPETRATOR OF HARASSMENT}

In addition to being a form of discrimination in terms of the EEA, harassment is also a well-established form of misconduct justifying dismissal. ${ }^{103}$ Serious incidents of harassment or continued harassment after warnings are dismissible offences and the employer must follow the procedure set out by

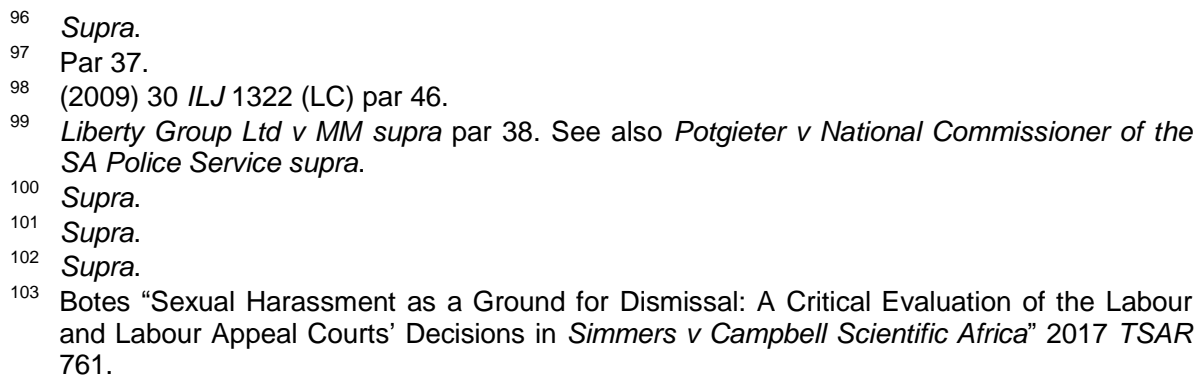

103 Botes "Sexual Harassment as a Ground for Dismissal: A Critical Evaluation of the Labour and Labour Appeal Courts' Decisions in Simmers v Campbell Scientific Africa" 2017 TSAR 761. 
the Code of Good Practice Regulating Dismissal (the Dismissal Code). ${ }^{104}$ In the context of sexual harassment, unwanted sexual attention becomes sexual harassment and misconduct if: ${ }^{105}$

“(a) The behaviour is persisted in, although a single incident of harassment can constitute sexual harassment; and/or

(b) The recipient has made it clear that the behaviour is considered offensive; and/or

(c) The perpetrator should have known that the behaviour is regarded as unacceptable.

It is submitted that the same approach would be taken in respect of any other form of harassment. It is not required that the harassment amounts to a criminal offence in order to qualify as a dismissible offence. ${ }^{107}$ What is important is that the requirements stated above are proved. However, in some instances, dismissal may not be an appropriate sanction. In those instances principles of corrective or progressive discipline must be followed.

In instances where an employee who has a mental illness is a harasser in the workplace, how should the employer handle such a misconduct? ${ }^{109}$ The

104 Item 7(5) of the Harassment Code. See also Campbell Scientific Africa (Pty) Ltd v Simmers [2016] 1 BLLR 1 (LAC).

105 Item 3 of the Harassment Code. See also National Union of Metalworkers of South Africa obo Botha / Welfit Oddy (Pty) Ltd [2016] 2 BALR 109 (MEIBC).

106 See UASA obo Zulu / Transnet Pipelines [2008] 5 BALR 415 (Tokiso), where the arbitrator found that employees of any status should be aware that serious misconduct is not tolerated, even if they are unable to read their employer's disciplinary rules and sexual harassment can never be justified on the basis that it is part of a "culture".

107 See Media 24 Ltd v Grobler [2005] 7 BLLR 649 (SCA); Reddy v University of Natal [1998] 1 BLLR 29 (LAC); Pretorius v Britz [1997] 5 BLLR 649 (CCMA); UASA obo Zulu / Transnet Pipelines supra and Campbell Scientific Africa (Pty) Ltd $v$ Simmers supra.

108 Maepe and Commission for Conciliation, Mediation \& Arbitration (2002) 23 ILJ 568 (CCMA). See also item 3(2)-(3) of the Code of Good Practice: Dismissal which provides "(2) the courts have endorsed the concept of corrective or progressive discipline. This approach regards the purpose of discipline as a means for employees to know and understand what standards are required of them. Efforts should be made to correct employees' behaviour through a system of graduated disciplinary measures such as counselling and warnings. (3) Formal procedures do not have to be invoked every time a rule is broken or a standard is not met. Informal advice and correction are the best and most effective way for an employer to deal with minor violations of work discipline. Repeated misconduct will warrant warnings, which themselves may be graded according to degrees of severity. More serious infringements or repeated misconduct may call for a final warning, or other action short of dismissal. Dismissal should be reserved for cases of serious misconduct or repeated offenses".

109 This submission does not in any way suggest that the fact that a person suffers from a mental illness means that the persons will commit an act of harassment or violence. Mental illness on its own may not lead to violence or harassment. Hiday, in analysing the connection between mental illness and violence, concludes that mental illness on its own does not lead to violence. However, certain factors together with mental illness may lead to some form of violence. These factors include: mentally ill persons being victims of violence from members of their close network and the larger social environment with both major mental illness and violence through the structured types of strains, events, situations, and individual experiences. For severe mental illness or even active psychosis to lead to violence, social factors must intervene. Hiday clearly explains the link between mental illness and violence in the following manner: "[S]uggesting that severe mental illness is coincidental to or indirectly associated with violence rather than being a direct cause. Violence by severely mentally ill persons is often produced by the co-morbidity of substance 
recent judgment in Jansen $v$ Legal Aid $S A,{ }^{110}$ the Labour Court may give direction on how the employer should respond to misconduct by an employee who has a mental illness. In Jansen $v$ Legal Aid $S A,{ }^{111}$ the employee was employed as a paralegal. Until 2010, when he was diagnosed with depression, he was an excellent employee and received performance awards. The employee continued to receive treatment and the employer was, at all times, aware of the employee's mental health. However, the employer did not do anything other than placing the employee on its wellness programme. His divorce, disputes with the employer on overtime payments and deductions for maintenance made his mental health condition worse. As his condition worsen, the employee was charged with, inter alia, gross insolence in that he turned his back in a disrespectful manner and walked away while his managers, were engaging with him about his absence; and refusal to obey a lawful and reasonable instruction in that he refused to conduct a prison visit after being specifically instructed to do so by his manager. At his disciplinary hearing, the employee argued that he committed the misconduct while suffering from a mental illness. The chairperson rejected the defence. The employee was found guilty and was dismissed.

The employee approached the Labour Court arguing that his dismissal was automatically unfair because it was based on the ground of disability, and it also amounted to unfair discrimination in terms of the EEA. The court noted that the employer was aware that the employee was suffering from a disability and that placed a duty on the employer to reasonably accommodate the employee and instead of dismissal, the employer should have instituted an incapacity enquiry. ${ }^{112}$ The employer should have, in deciding to dismiss, considered the circumstances under which the misconduct occurred and the effect of the employee's mental illness on his conduct. ${ }^{113}$ The court found that the conduct of the employer in ignoring the employee's mental health had potential to impair the employee's fundamental human dignity and, accordingly, falls within the grounds prohibited by section $187(1)(f)$ of the LRA. ${ }^{114}$ The court concluded that the employee's misconduct was inextricably linked to his mental condition and therefore, was dismissed because of his mental illness. ${ }^{115}$

The court reached this decision taking into account the evidentiary burden placed on the employer and the employee. The employee led adequate evidence to indicate that he had suffered from depression and the respondent was, throughout, aware of his mental illness. ${ }^{116}$ Therefore, the employee made out a prima facie case and, thus, discharged the evidential

abuse/dependence and/or ASP/psychopathy, which are themselves caused by social factors. In other cases, violence arises out of tense social situations." See Hiday "Understanding the Connection Between Mental Illness and Violence" 1997 20(4) 110 Supra.

111 Supra.

112 Jansen $v$ Legal Aid SA supra par 43

113 lbid.

114 Jansen $v$ Legal Aid SA supra par 44

115 Jansen $v$ Legal Aid SA supra par 50

116 Jansen $v$ Legal Aid SA supra par 51 
burden to show that the reason for his dismissal was on account of his mental illness. ${ }^{17}$ It is submitted that the case in Jansen $v$ Legal Aid SA, ${ }^{18}$ clearly indicates that where the employee commits an act of harassment, dismissal will be automatically unfair if the conduct was because of the mental illness. The employer will have the duty to accommodate the employee. It is recognised that, in Jansen $v$ Legal Aid $S A,{ }^{119}$ the employee was not charged with harassment. However, the same principle would be applicable because in this case the employee was charged with a misconduct.

\section{CONCLUSION}

Where an employee has a mental illness, the employer is required to reasonably accommodate the employee. Failure to accommodate amounts to unfair discrimination. The duty to accommodate arises if the employer is

117 Ibid. See also SACWU v Afrox Ltd (1999) 20 ILJ 1718 (LAC) par 32 where the court found that: "The enquiry into the reason for the dismissal is an objective one, where the employer's motive for the dismissal will be merely one of a number of factors to be considered. This issue (the reason for the dismissal) is essentially one of causation and I can see no reason why the usual twofold approach to causation, applied in other fields of law, should not be utilised here (compare $S$ v Mokgethi 1990 (1) SA 32 (A) at 39D-41A; Minister of Police $v$ Skosana 1977 (1) SA 31 (A) at 34). The first step is to determine factual causation: was participation or support, or intended participation or support, of the protected strike a sine qua non (or prerequisite) for the dismissal? Put another way, would the dismissal have occurred if there was no participation or support of the strike? If the answer is yes, then the dismissal was not automatically unfair. If the answer is no, that does not render the dismissal automatically unfair; the next issue is one of legal causation, namely whether such participation or conduct was the "main" or "dominant", or "proximate" or "most likely" cause of the dismissal. There are no hard and fast rules to determine the question of legal causation (compare $S v$ Mokgethi at 40). I would specifically venture to suggest that the most practical way of approaching the issue would be to determine what the most probable inference is that may be drawn from the established facts as a cause of the dismissal, in much the same way as the most probable or plausible inference is drawn from circumstantial evidence in civil cases. It is important to remember that at this stage the fairness of the dismissal is not yet an issue ... Only if this test of legal causation also shows that the most probable cause for the dismissal was only participation or support of the protected strike, can it be said that the dismissal was automatically unfair in terms of $s$ $187(1)(a)$. If that probable inference cannot be drawn at this stage, the enquiry proceeds a step further." In Kroukam v SA Airlink (Pty) Ltd (2005) 26 ILJ 2153 (LAC) par 24-25 the court explaining the test observed that: "In my view, s 187 imposes an evidential burden upon the employee to produce evidence which is sufficient to raise a credible possibility that an automatically unfair dismissal has taken place. It then behoves the employer to prove to the contrary, that is to produce evidence to show that the reason for the dismissal did not fall within the circumstance envisaged in $\mathrm{S} 187$ for constituting an automatically unfair dismissal". Further in State Information Technology Agency Ltd v Sekgobela (2012) 33 ILJ 2374 (LAC) par 15, the court reiterated the test and stated that: "In cases where it is alleged that the dismissal is automatically unfair, the situation is not much different save that the evidentiary burden to produce evidence that is sufficient to raise a credible possibility that an automatically unfair dismissal has taken place rests on the applicant (employee). If the applicant succeeds in discharging his evidentiary burden then the burden to show that the reason for the dismissal did not fall within the circumstances envisaged by $s$ 187(1) of the LRA rests with (employer). It is evident therefore that a mere allegation that there is a dismissal is not sufficient but the employee must produce evidence that is sufficient to raise a credible possibility that there was an automatically unfair dismissal."

118 Supra.

119 Supra. 
aware of the disability. This may be because the employee has disclosed the disability or the disability was reasonably self-evident to the employer. The nature of the accommodation will depend on the circumstances of the particular case. Where the accommodation requires significant or considerable difficulty, the employer will be excused from reasonably accommodating the employee.

When faced with harassment perpetrated by an employee who has a mental illness, the EEA and the LRA provides various provisions that the employer must take into account to escape liability for harassment and to avoid a claim for automatically unfair dismissal. The EEA prohibits unfair discrimination on the grounds of disability, which includes mental illness. Harassment is a form of discrimination against a victim, and it is prohibited in terms of the EEA. The employer may be liable for the harassment, where it fails to take reasonable steps to prevent such harassment. The employer will be liable if the harassment was brought to its attention and it failed to take reasonable steps to prevent it, even if no further act of harassment occurs.

Harassment is also a form of misconduct. Under certain circumstances, harassment may be a dismissible offence and the reasonable step that the employer is required to take, to prevent harassment, may be to institute disciplinary proceedings against the offending employee. Where the offending employee has a mental illness, dismissal of such an employee would amount to an automatically unfair dismissal if he/she committed the misconduct because of the mental illness. In terms of Jansen $v$ Legal Aid $S A,{ }^{120}$ the employee is required to reasonably accommodate such an employee. However, when the reasonable accommodation requires significant or considerable difficulty, the employer has no duty to accommodate the offending employee and such dismissal may be fair. Repeated incidents of harassment by an employee who has a mental illness may be an indication that it would be unjustifiably hard for the employer to reasonably accommodate the employee. A serious act of harassment together with the requirement to provide a safe working environment, and the possible liability of the employer may also be an indication that reasonable accommodation would be unjustifiably hard for the employer. However, this will depend on the circumstances of the case. The court, Jansen $v$ Legal Aid $S A,{ }^{121}$ also suggested that, in such cases the employer may also institute an enquiry for incapacity. 